\title{
Factors affecting home range size and overlap in Akodon azarae (Muridae: Sigmodontinae) in natural pasture of Argentina
}

\author{
Jose W. PRIOTTO and Andrea R. STEINMANN
}

\begin{abstract}
Priotto J. W. and Steinmann A. R. 1999. Factors affecting home range size and overlap in Akodon azarae (Muridae: Sigmodontinae) in natural pasture of Argentina. Acta Theriologica 44: 37-44.

Differences in home range size in relation to sex, age, breeding and non-breeding periods were studied. Home range size and overlap were examined at different densities values in populations of Akodon azarae (Fischer, 1829) on railway banks in southern Córdoba Province (Argentina). The sampling was carried out between October 1994, and February 1997, using the capture-mark-recapture method. Home range size in A. azarae was determined by sex and breeding period, and it was independent of the observed density values. Home range size of males was always larger than that of females. Increase of population density during the breeding period affected the degree of intersexual overlap of home range.

Departamento de Ciencias Naturales, Universidad Nacional de Río Cuarto. Agencia Postal N 3, 5800 Río Cuarto, Córdoba, Argentina; e-mail: jpriotto@exa.unrc.edu.ar

Key words: Akodon azarae, home range size, overlap, murids
\end{abstract}

\section{Introduction}

Home range size can vary within a species due to differences in the quality of habitat, distribution and abundance of food, or population density (Hixon 1980, Ostfeld 1985, Wolff 1985). For example, home range in Peromyscus leucopus and Peromyscus maniculatus was smaller in bushy, favorable habitats than in more open, less favorable habitats (Metzgar 1971, Van Horne 1982). Access to additional food supply resulted in a significant reduction of home range size in Microtus townsendii (Taitt and Krebs 1981) and in Peromyscus maniculatus (Taitt 1981). On the other hand, the effect of density on home range size is less clear. In some cases, high densities caused a reduction in home range size and/or an increase in the degree of overlap of home range (Getz 1961, Taitt 1981, Ostfeld et al. 1985, Ostfeld 1986, Erlinge et al. 1990); in other cases, home range size was independent of population density (Batzli 1968, Bondrup-Nielsen 1986). Home range size is also affected by sex, age and social condition (Mazurkiewicz 1971, Maza et al. 1973, Webster and Brooks 1981). In rodents, movement is likely to be limited by 
breeding activity (Ostfeld 1985, Erlinge et al. 1990). So, in polygynous mating systems, males show larger home ranges than females because they are subjected to sexual selection favoring mating with a greater number of females (Madison 1978, 1980, Ostfeld 1985). On the other hand, social condition plays a significant role in space use because the presence of dominant animals affects the subordinate ones, inhibiting their movements or stimulating their emigration (Bujalska 1973, Myton 1974).

In this study, we provide information about spacing behaviour of Akodon azarae (Fischer, 1829), one of the most abundant species living in the agroecosystems of southern Córdoba Province (Argentina) (Priotto and Polop 1997), and discuss: (1) the differences in home range size, in relation to sexes, ages, breeding and non-breeding periods; and (2) home range size and overlap according to sexes, breeding and non-breeding periods in relation to population densities.

\section{Material and methods}

The study was carried out in Chucul $\left(64^{\circ} 20^{\prime} 09^{\prime \prime W}, 32^{\circ} 21^{\prime} 06^{\prime \prime} \mathrm{S}\right)$, Río Cuarto Department, Córdoba Province, Argentina. Phytogeographically, this region corresponds to "Provincia del Espinal" "Distrito del Algarrobo" (Cabrera 1953), wich is a plain at a low elevation $(600-900 \mathrm{~m})$ with vegetation dominated by algarrobo (Prosopis alba, P. nigra), accompanied by quebracho blanco (Aspidosperma quebracho blanco), mistol (Zizyphus mistol) and itin (Portulaca kuntzie). The vegetation of the study site, however, has undergone marked alterations as a result of agriculture and cattle farming. At present, the landscape consists mainly of individual cropfields, surrounded by wire fences with borders dominated by weedy species. In the area, the railway banks are an environment where some rodent populations reach high densities. This plant community is characterised by pasture interspersed with bushes, and was selected for sampling. Despite the influence of nearby crop fields, it bears some resemblance to indigenous vegetation. This community, with a homogeneous plant cover of about $85 \%$ throughout the year, is composed mainly of Diplotaxis tenuifolia, Sorghum halepense, Iresine difusa, Conium maculatum, Setaria geniculata and Lippia turbinata, and has a high availability of seeds in soil (A. Previtali pers. comm.).

Rodents were caught in October 1994 through February 1997, in traps arranged in a grid of $6 \times$ 10 traps $(37.5 \mathrm{~m} \times 67.5 \mathrm{~m})$ with an interstation interval of $7.5 \mathrm{~m}$. One Sherman live trap, placed at each station, was baited with a mixture of peanut butter and cow fat. Monthly censuses (trapping sessions) were taken in periods of 10 successive days. Traps were checked daily in the morning.

Trapped animals were weighed and marked with a numerical code in the ears. Sex and reproductive state (males: scrotal or abdominal testicles, females: perforated or imperforated vagina, nipples visible or not) were also recorded. Each captured animal was assigned to the category of juvenile or adult according to Crespo et al. (1970). Individuals weighting $12-21 \mathrm{~g}$ were considered "Juvenile" and individuals with body weights between 22-31 g were considered "Adult".

Data were analysed by considering separately the non-breeding period (May to August) and the breeding period (September to April). This division was based on the fact that between May and August $100 \%$ of the males and females did not present breeding activity (abdominal testicles and imperforated vagina respectively), whereas, between September and April, a large proportion of males $(96.56 \%)$ and females $(86.21 \%)$ became reproductive (scrotal testicles and perforated vagina, nipples visible and evidence of pregnancy respectively).

Population size was estimated by computing the minimum number of animals known alive (MNKA) (Krebs 1966). For the analysis of home range size in relation to different values of population 
density, these were divided into low-density (MNKA $<10$ and MNKA $<20$ for breeding and non-breeding periods respectively) and high-density (MNKA $>10$ and MNKA $>20$ for breeding and non-breeding periods respectively). This division of low- and high-density was based on values of abundance of A. azarae observed by Priotto and Polop (1997), from April 1990 throughout February 1995, at the same location of this study.

Monthly home range size configuration was obtained by means of the Boundary Strip Method (Stickel 1954), and area was determined by the method suggested by Calhoun and Casby (1958). The number of captures for each home range estimate varied from 5 to 8 .

Home range overlap was estimated for each animal in each trapping session. We calculated proportional overlap by measuring the area in each home range (the target animal) that was shared by all other animals of the same sex (intrasexual overlap) or all other animals of the opposite sex (intersexual overlap) and dividing by the area of the target animals home range. The authors assume, as suggested by Batzli and Henttonen (1993), that home range overlap that is significantly lower than would be expected by random placement indicates that individuals are avoiding one another, and consider this evidence of territorial behaviour.

To analyze home range size in relation to sex, breeding period and population density, a three-factor ANOVA was made. The relationship between home range size and age (adults and juveniles) was also studied during the breeding period employing a one-factor ANOVA. In all cases, normality assumption was tested by the Kolmogorov-Smirnov test, and variance homogeneity was tested by the Bartlett's test.

\section{Results}

From October 1994 to February 1997, a total of 270 A. azarae individuals (736 captures) were obtained during 12,000 night traps. In our population, mean abundances were minimal at the beginning of the breeding period, and maximum at the beginning of the non-breeding period, with variation within each period among the sampling years.

During the sampled years, 83 home ranges were estimated; 50 during the breeding period (20 and 30 home ranges of males and females respectively) and 33 during the nonbreeding period (17 and 16 home ranges of males and females respectively). Males showed a minimal home range size of $98 \mathrm{~m}^{2}$ and a maximum home range size of $857.5 \mathrm{~m}^{2}$; meanwhile, minimum and maximum home range size for females were $98 \mathrm{~m}^{2}$ and $441 \mathrm{~m}^{2}$ respectively. This wide scattering of home range sizes generated non-homogeneous variances $(p<0.05)$, with a normal distribution of data $(p>0.05)$. In order to accomplish the assumption of variance homogeneity of ANOVA, it was necessary to employ a logarithmic transformation of the response variables (home range size). All animals which established home range during the breeding period were sexually mature.

The number of observations $(n)$, average values and their standard deviations of home range size by sex, sampling period and population density are shown in Table 1. Home range size of males was larger than that of females $(F=18.20$, $\mathrm{df}=1,75, p<0.05$ ), either in the breeding period or the non-breeding period, and at high or low densities. Home range size also varied between sampling periods, and it was larger in the breeding period $(F=4.02, \mathrm{df}=1,75, p<0.05)$. This was mainly observed in males, since home range size of females was almost constant 
Table 1. Average values of home range size in Akodon azarae according to sex, sampling period and population density on railway banks (Río Cuarto, Córdoba, Argentina).

\begin{tabular}{|c|c|c|c|c|}
\hline \multirow{3}{*}{ Density } & \multicolumn{4}{|c|}{ Home range size $\left(\mathrm{m}^{2}\right)$} \\
\hline & \multicolumn{2}{|c|}{ Males } & \multicolumn{2}{|c|}{ Females } \\
\hline & $n$ & $\bar{x} \pm \mathrm{SD}$ & $n$ & $\bar{x} \pm \mathrm{SD}$ \\
\hline & \multicolumn{4}{|c|}{ Breeding period } \\
\hline High & 9 & $428 \pm 165$ & 18 & $284 \pm 78$ \\
\hline \multirow[t]{2}{*}{ Low } & 11 & $497 \pm 202$ & 12 & $251 \pm 82$ \\
\hline & \multicolumn{4}{|c|}{ Non-breeding period } \\
\hline High & 12 & $402 \pm 176$ & 5 & $225 \pm 94$ \\
\hline Low & 5 & $300 \pm 65$ & 11 & $278 \pm 99$ \\
\hline
\end{tabular}

throughout the study (Table 1). No significant differences in home range size were observed between high and low population densities $(F=0.001$, df $=1,75$, $p>0.05$ ). First-order and second-order interactions were not statistically significant $(p>0.05)$ and indicated independence between the studied factors (sex, breeding period and population density).

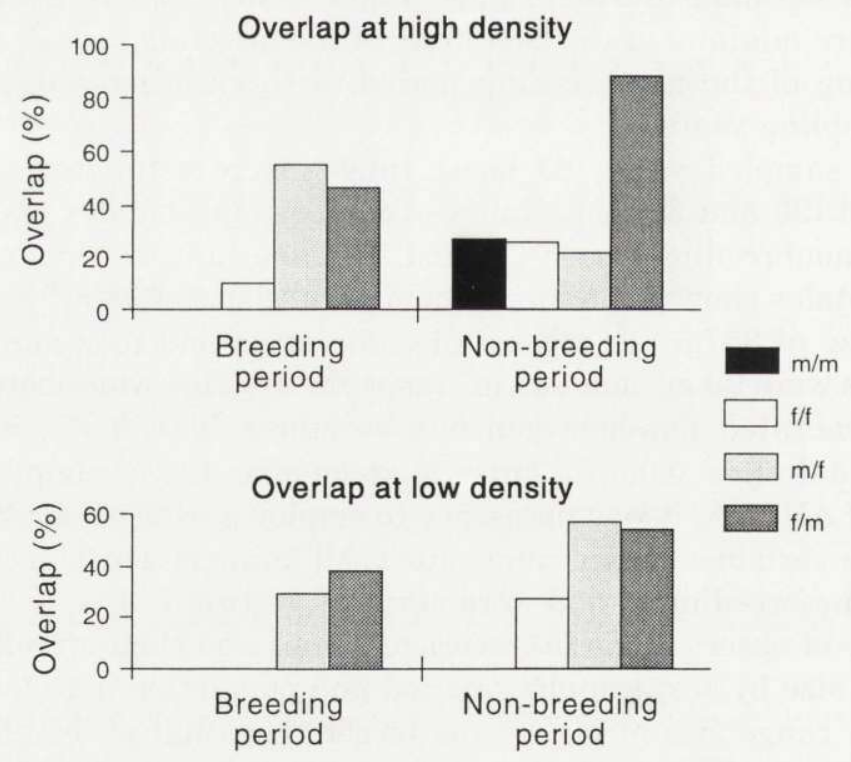

Fig. 1. Percentages of home range overlap in Akodon azarae at high and low population densities during the breeding period and the non-breeding period on railway banks (Río Cuarto, Córdoba, Argentina). Intrasexual overlap: $\mathrm{m} / \mathrm{m}$ and $\mathrm{f} / \mathrm{f}$. Intersexual overlap: $\mathrm{m} / \mathrm{f}$ and $\mathrm{f} / \mathrm{m}$. $(\mathrm{m}-\mathrm{males}, \mathrm{f}-$ females). 
The study of age in relation to home range size was made only in the breeding period because both juvenile and adult animals were present. Adults showed an average home range size $\left( \pm\right.$ SD) of $450.67 \pm 168.27 \mathrm{~m}^{2}$ and $261.13 \pm 83.68 \mathrm{~m}^{2}$ for males and females respectively; whereas for juveniles, home range size was 488.13 $\pm 218 \mathrm{~m}^{2}$ for males and $287.94 \pm 73.40 \mathrm{~m}^{2}$ for females. To make the ANOVA, a logarithmic transformation of the data was needed. Home range size did not vary significantly between the two categories of studied ages $(F=0.83, \mathrm{df}=1,48$, $p>0.05)$.

Average values for the percentage of home range overlap in each sampling period, at different density values are shown in Fig. 1. Overlap between males was only observed in the non-breeding period at high density values; whereas overlap between females was dependent on breeding period and independent of the observed abundance values. Breeding females overlapped slightly at high densities (10\%) but not at all when densities were low. The highest overlap values observed were intersexual $(\mathrm{m} / \mathrm{f}, \mathrm{f} / \mathrm{m})$, recording similar values (home range utilization between males and females) both in the breeding period (at different density values) and the non-breeding period (at low density). However, in the non-breeding period and at high density, females utilized a significant percentage of male home range ( $87 \%$ ), whereas males used only $22 \%$ of the female home range.

\section{Discussion}

According to our results, home range size in A. azarae was determined by sex and breeding period, and was independent of population abundance. Even though home range size of males was always larger than that of females, this was more evident in the breeding period. Female home ranges in the breeding period represented $58 \%$ of the home range area of males; whereas, in the non-breeding period, home range size of females represented $72 \%$ of the male area. These sexual differences in home range size are considered a typical feature of rodent species with a promiscuous/polygynous mating system (Gaulin and FitzGerald 1988). In males spacing behaviour is strongly influenced by mate search; whereas in females food distribution and abundance are most important (Emlen and Oring 1977, Ostfeld 1985, 1986, Ostfeld et al. 1985). This mating system in A. azarae was suggested by Zuleta and Bilenca (1992).

At high densities, in numerous rodent species, a reduction of home range size in both sexes (Getz 1961, Ostfeld 1986, Erlinge et al. 1990) or in one of them (Bondrup-Nielsen 1986, Urayama 1995) has been observed. In A. azarae, as was reported by Batzli (1968) for Microtus californicus, density did not affect home range size of males or females. Nevertheless, intersexual overlap did increase at high densities. In the breeding period, when males showed territorial behaviour, the degree of overlap in home ranges with that of females was nearly doubled (Fig. 1). Considering that home range overlap of females with males did not change, 
male behaviour could be due to the fact that an increase of density would result in an enlarged number of contacts with reproductive females, ie, the resource of interest would increase. This, in an environment with available reproductive spaces (Heske and Bondrup-Nielsen 1990). In this study, at high densities, the environment allowed the establishment of six new breeding spaces (reproductive females) (Table 1). In the non-breeding period, differences observed in the intersexual overlap in relation to density could not be explained in terms of the spacing behaviour. This is because in that period, as recorded by Ostfeld (1985) and Erlinge et al. (1990) in other rodent populations, a loss of male and female territoriality was observed. This allows an analysis of intersexual overlap as a whole, with no distinction between home range overlap of males over females vs. females over males.

Unlike that observed by Mikesic and Drickamer (1992) in Mus musculus domesticus and that suggested by Brown (1953), we did not find any differences in home range size between adult and juvenile individuals of $A$. azarae. This could be due to the fact that in our study, animals which established home ranges were reproductively active, in spite of being classified as juveniles by their weights.

We conclude that differences in home range size in $A$. azarae are determined by sex and breeding period, and that increase of population density does not influence home range size, but it does affect the degree of intersexual overlap in the breeding period.

Acknowledgements: We thank Marcos P. Torres for collaboration in the field. The help of M. V. Daga for the English version is also recognised. This research was made possible by grants from the Consejo de Investigación de la Provincia de Córdoba (CONICOR), and Secretaría de Ciencia y Técnica (SECyT) for Dr Jaime Polop, Universidad Nacional de Río Cuarto. We also thank two anonymous reviewer for their suggestions.

\section{References}

Batzli G. O. 1968. Dispersion patterns of mice in California annual grassland. Journal of Mammalogy 49: $239-250$.

Batzli G. O. and Henttonen H. 1993. Home range and social organization of the singing vole (Microtus miurus). Journal of Mammalogy 74: 868-878.

Bondrup-Nielsen S. 1986. Analysis of spacing behaviour of females from a live-trapping study of Clethrionomys gapperi. Annales Zoologici Fennici 23: 261-267.

Brown R. Z. 1953. Social behavior, reproduction, and population changes in the house mouse (Mus musculus L.) Ecological Monographs 23: 217-240.

Bujalska G. 1973. The role of spacing behaviour among females in the regulation of the reproduction in the bank vole. Journal of Reproduction and Fertility (Supplement) 19: 465-474.

Cabrera A. 1953. Esquema fitogeográfico de la Republica Argentina. Revista Museo de la Plata (Botánica) 8: 87-168.

Calhoun J. B. and Casby J. B. 1958. Calculation of home range and density of small mammals. U. S. Public Health Monographs 55: 1-24.

Crespo J. A., Sabattini M. S., Piantanida M. J. and de Villafañe G. 1970. Estudios ecológicos sobre roedores silvestres. Observaciones sobre densidad, reproducción y estructuras de las comunidades 
de roedores silvestres en el sur de la Provincia de Córdoba. Ministerio de Bienestar Social, Secretaria de Estado de Salud Pública, Buenos Aires, Argentina: 1-45.

Emlen S. T. and Oring L. W. 1977. Ecology, sexual selection , and the evolution of mating systems. Science 197: 215-223.

Erlinge S., Hoogenboom I., Agrell J., Nelson J. and Sandell M. 1990. Density-related home-range size and overlap in adult field voles (Microtus agrestis) in southern Sweden. Journal of Mammalogy 71: 597-603.

Gaulin S. J. and FitzGerald R. W. 1988. Home range size as a predictor of mating systems in Microtus. Journal of Mammalogy 69: 311-319.

Getz L. L. 1961. Home ranges, territoriality, and movement of the meadow vole. Journal of Mammalogy 42: 24-36.

Heske E. J. and Bondrup-Nielsen S. 1990. Why spacing behavior does not stabilize density in cyclic populations of microtine rodents. Oecologia 83: 91-98.

Hixon M. 1980. Food production and competitor density as determinants of feeding territory size. The American Naturalist 115: 510-530.

Krebs C. J. 1966. Demographic changes in fluctuating populations of Microtus californicus. Ecological Monographs 36: 239-273.

Madison D. M. 1978. Movement indicators of reproductive events among female meadow voles as revealed by radiotelemetry. Journal of Mammalogy 59: 835-843.

Madison D. M. 1980. Space use and social structure in meadow voles, Microtus pennsylvanicus. Behavioural Ecology and Sociobiology 7: 65-71.

Maza B. G., French N. R. and Aschwanden A. P. 1973. Home range dynamics in a population of heteromyid rodents. Journal of Mammalogy 54: 405-425.

Mazurkiewicz M. 1971. Shape, size and distribution of home ranges of Clethrionomys glareolus (Schreber, 1780). Acta Theriologica 16: 23-60.

Metzgar L. H. 1971. Behavioral population regulation in the wood-mouse, Peromyscus. American Midland Naturalist 86: 434-448.

Mikesic D. G. and Drickamer L. C. 1992. Factors affecting home-range size in house mice (Mus musculus domesticus) living in outdoor enclouser. American Midland Naturalist 127: 31-40.

Myton B. 1974. Utilization of space by Peromyscus leucopus and other small mammals. Ecology 55: 277-290.

Ostfeld R. S. 1985. Limiting resources and territoriality in microtine rodents. The American Naturalist 126: $1-15$.

Ostfeld R. S. 1986. Territotiality and mating system of California voles. Journal of Animal Ecology 55: 691-706.

Ostfeld R. S., Lidicker W. Z. Jr and Heske J. 1985. The relationship between habitat heterogeneity, space use, and demography in a population of California voles. Oikos 45: 433-442.

Priotto J. W. and Polop J. J. 1997. Space and time use in syntopic populations of Akodon azarae and Calomys venustus (Rodentia, Muridae). Zeitschrift für Säugetierkunde 62: 30-36.

Stickel L. F. 1954. A comparison of certain methods of measuring ranges of small mammals. Journal of Mammalogy 35: 1-5.

Taitt M. J. 1981. The effect of extra food on small rodent populations: I. Deer mice (Peromyscus maniculatus). Journal of Animal Ecology 50: 111-124.

Taitt M. J. and Krebs C. J. 1981. The effect of extra food on small rodent populations: II. Voles (Microtus townsendii). The Journal of Animal Ecology 50: 125-137.

Urayama K. 1995. Size and overlap of home range in a high density population of the Japanese field vole Microtus montebelli. Acta Theriologica 40: 249-256.

Van Horne B. 1982. Niches of adult and juvenile deer mice (Peromyscus maniculatus) in seral stages of coniferous forest. Ecology 63: 992-1003.

Webster A. B. and Brooks R. J. 1981. Social behavior of Microtus pennsylvanicus in relation to seasonal changes in demography. Journal of Mammalogy 62: 738-751. 
Wolff J. O. 1985. The effects of density, food, and interespecific interference on home range size in Peromyscus leucopus and Peromyscus maniculatus. Canadian Journal of Zoology 63: 2657-2662.

Zuleta G. A. and Bilenca D. N. 1992. Seasonal shifts within juvenile recruit sex ratio of Pampas mice (Akodon azarae). Journal of the Zoological Society of London 227: 397-404.

Received 1 September 1997, accepted 10 November 1998. 